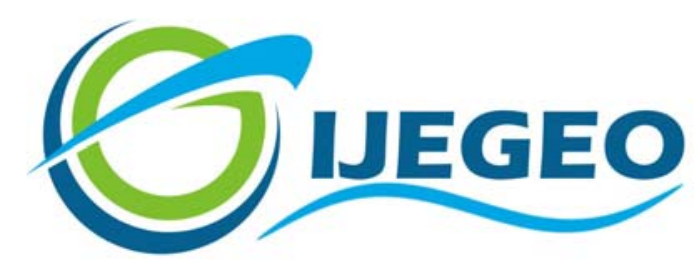

International Journal of Environment and Geoinformatics (IJEGEO) is an international, multidisciplinary, peer reviewed, open access journal.

\title{
Proposal for a manned underwater habitat program
}

\section{Mertin HENKE}

\author{
Chief in Editor
}

Prof. Dr. Cem Gazioğlu

\section{Co-Editors}

Prof. Dr. Dursun Zafer Şeker, Prof. Dr. Şinasi Kaya,

Prof. Dr. Ayşegül Tanık and Assist. Prof. Dr. Volkan Demir

Editorial Committee (January 2021)

Assoc. Prof. Dr. Abdullah Aksu (TR), Assit. Prof. Dr. Uğur Algancı (TR), Prof. Dr. Bedri Alpar (TR), Assoc. Prof. Dr. Aslı Aslan (US), Prof. Dr. Levent Bat (TR), Prof. Dr. Paul Bates (UK), İrşad Bayırhan (TR), Prof. Dr. Bülent Bayram (TR), Prof. Dr. Luis M. Botana (ES), Prof. Dr. Nuray Çağlar (TR), Prof. Dr. Sukanta Dash (IN), Dr. Soofia T. Elias (UK), Prof. Dr. A. Evren Erginal (TR), Assoc. Prof. Dr. Cüneyt Erenoğlu (TR), Dr. Dieter Fritsch (DE), Prof. Dr. Çiğdem Göksel (TR), Prof.Dr. Lena Halounova (CZ), Prof. Dr. Manik Kalubarme (IN), Dr. Hakan Kaya (TR), Assist. Prof. Dr. Serkan Kükrer (TR), Assoc. Prof. Dr. Maged Marghany (MY), Prof. Dr. Michael Meadows (ZA), Prof. Dr. Nebiye Musaoğlu (TR), Prof. Dr. Masafumi Nakagawa (JP), Prof. Dr. Hasan Özdemir (TR), Prof. Dr. Chryssy Potsiou (GR), Prof. Dr. Erol Sarı (TR), Prof. Dr. Maria Paradiso (IT), Prof. Dr. Petros Patias (GR), Prof. Dr. Elif Sertel (TR), Prof. Dr. Nüket Sivri (TR), Prof. Dr. Füsun Balık Şanlı (TR), Prof. Dr. Uğur Şanlı (TR), Duygu Ülker (TR), Prof. Dr. Seyfettin Taş (TR), Assoc. Prof. Dr. Ömer Suat Taşkın (TR), Assist. Prof. Dr. Tuba Ünsal (TR), Dr. Manousos Valyrakis (UK), Dr. İnese Varna (LV), Dr. Petra Visser (NL), Prof. Dr. Selma Ünlü (TR), Assoc. Prof. Dr. Oral Yağcı (TR), Prof. Dr. Murat Yakar (TR), Assoc. Prof. Dr. İ. Noyan Yı1maz (AU); Assit. Prof. Dr. Sibel Zeki (TR)

Abstracting and Indexing: TR DIZIN, DOAJ, Index Copernicus, OAJI, Scientific Indexing Services, International Scientific Indexing, Journal Factor, Google Scholar, Ulrich's Periodicals Directory, WorldCat, DRJI, ResearchBib, SOBIAD 
Short Communication

\title{
Proposal for a manned underwater habitat program
}

\author{
Martin Henke (iD \\ Founder of CalamarPark, Antalya, Turkey
}

E-mail: mart@calamarpark.com

Received: 01 Sept 2020 Accepted: 03 Dec 2020

How to cite: Henke, M. (2021). Proposal for a manned underwater habitat program, .International Journal of Environment and Geoinformatics (IJEGEO), 8(1): 110-112. doi: 10.30897/ijegeo.789044

\begin{abstract}
Nearly 50 years after the great era of manned underwater habitats CalamarPark.com proposes a new approach in designing new structures for underwater living. These habitats should serve not only scientific or military goals, but involve civil participants in order to create a closer relation to the oceans and an increased awareness for marine protection. For this concept 65 habitats were studied and compared, and the potential applications of 10 sectors had been evaluated. These investigations resulted in a concept for a modular underwater habitat analogue to the International Space Station that is supposed to serve long-term research and opens doors to a permanent presence of human beings on the seafloor.
\end{abstract}

Keywords: Underwater Habitat, Saturation Diving, Aquanautic

\section{Introduction}

Underwater space has been the subject of various scientific fields. In the field of architectural design, projects are generally limited to the areas of construction techniques for underwater as a civil engineering problem; underwater tourism; and underwater research. A much less researched area is ocean colonisation permanent human settlement of oceans- and its architecture (Burak et al., 2004; Varinlioğlu and Pasin, 2018).

The subject of underwater habitation is closely related to saturation diving. A body is saturated with inert gas during a stay of several hours at a certain depth, so its decompression time from that depth does not increase further. The inhabitant of an underwater station is thus automatically in a saturated state, so that a sudden emergence to the surface is no longer an option. This final decompression time can be very long depending on the depth. Divers of Aquarius Reef Base in Florida at a depth of $19 \mathrm{~m}$ decompress for 15 hours and 45 minutes in the end of a mission. They spend this time within the closed habitat, while the pressure is slowly adjusted to that of the water surface. A short recompression follows at the end so that the divers can leave the habitat as after an ordinary dive and emerge to the surface.

The 60's and 70's witnessed a race for dominance on the seabed. The reason for this was the search for suitable techniques for oil production, as well as scientific and military programs. Many countries developed and launched a total of approximately 65 habitats for this purpose. The development eventually led to the construction of Sealab II with a living space of $63 \mathrm{~m} 2$, which allowed people to live for long periods at a depth of more than 60 metres. Jacques Cousteau built a habitat which he used successfully for several weeks at $100 \mathrm{~m}$. The results of these programs laid the foundation for modern offshore diving. Today only two remarkable habitats are still in use. "Aquarius Reef Base" in $20 \mathrm{~m}$ depth, and the former habitat "La Chalupa", today "Jules Undersea Lodge", a 9m deep underwater hotel. The use of underwater habitats for industrial purposes was ultimately replaced by mobile saturation diving facilities in the hulls of corresponding ships, whose divers living in on board pressure chambers are brought to their operation depth with pressure capsules and after a few hours in the same way back. Underwater stations thus tragically abolished themselves through their own further development. (Miller and Koblick, 1984).

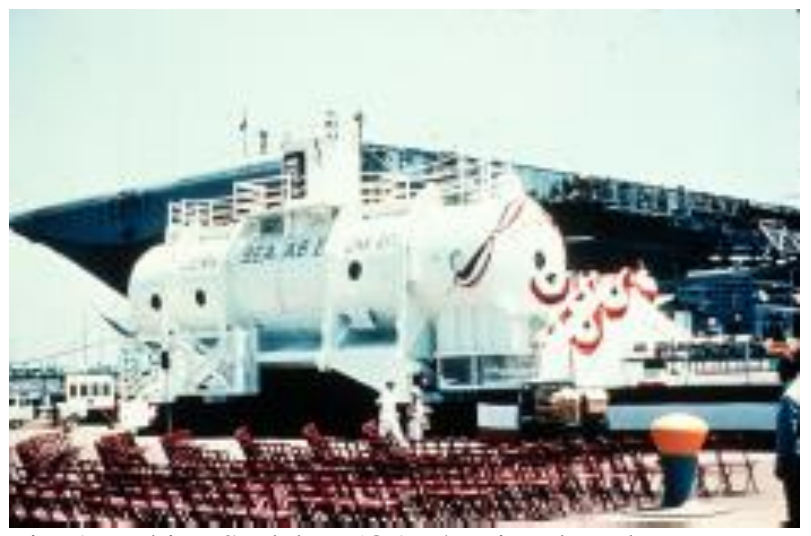

Fig. 1: Habitat Sealab II (OAR/National Undersea Research Program (NURP); U.S. Navy .

In recent years, however, there has been a growing interest in the possibility of living underwater. The 
reason for this could be a move away from concentration on a single user sector; interdisciplinary and civilian users are now on the list of potential customers. Spectacular projects such as "Poseidon Resorts", "Hydropolis" or "Sea Orbiter" combine tourism and science and were very close to be realized. In Italy, several participants of a television show called "Progetto Abissi" lived in small habitats.

At the same time, new technologies for remotely operated vehicles (ROVs) are rapidly developed, reaching easily any depth and allow studies to be carried out without endangering human life. However, voices like the American aquanaut Dr. Sylvia Earle claim that "we have to maintain a human presence on the seafloor" (URL 3).

As an advantage of underwater habitats, the ability to accommodate divers from greater depths is repeatedly mentioned. The technique behind this is called "saturation excursion diving". It means that the nodecompression depth (the depth that does not require decompression stops during ascent; about $8 \mathrm{~m}$ for dives from the water surface) increases with saturation depth (also called storage depth). At a saturation depth of $250 \mathrm{~m}$, the no-decompression depth is $294 \mathrm{~m}$, so divers could dive $44 \mathrm{~m}$ deeper for several hours before returning to the habitat at $250 \mathrm{~m}$ without decompression. But even at lower depths the effect shows up: at a storage depth of $20 \mathrm{~m}$, the no-decompression depth is about $33 \mathrm{~m}$, so divers could move almost indefinitely to $33 \mathrm{~m}$ and return to the habitat without decompression stops. A diver from the surface, on the other hand, would have to ascend after a few minutes in order to avoid decompression duties or accidents. Living in a habitat on the seafloor instead, he would also have the opportunity to study his surroundings 24 hours a day. (Lettnin, 1998)

It has to be noted that after many decades of industrial, scientific and military exploration of the marine environment there is sufficient knowledge of the human physiology and the engineering aspects. Michael Schutte, naval architect of Poseidon Resorts summarized: "From the technical point of view building an sophisticated underwater station is not a problem at all."

\section{Method}

CalamarPark.com, an international initiative for the development of a new generation of manned underwater habitats, has been working since 2006 on their potential applications. It is obvious that no single institution would be willing to build a habitat or rent an offshore deep-sea diving facility, for example, for the exploration of a historical wreck. So the question arose, how a habitat could serve various sectors to maintain its own funding. For this question, the following sectors were defined and surveyed:

- environmental protection

- underwater archaeology

- marine sciences/oceanography
- education

- advertisement

- entertainment

- tourism

\section{Result}

The result of these surveys led to the concept of a mobile underwater habitat for use in the Mediterranean, which directly neighbours 21 countries and indirectly all countries of the European Union, each with its own programs in the above-mentioned 7 main sectors. Depending on the individual mission goal it could be used at different depths. The habitat would have the size of a standard freight container ("tank container") and would be easily transportable by land and sea.

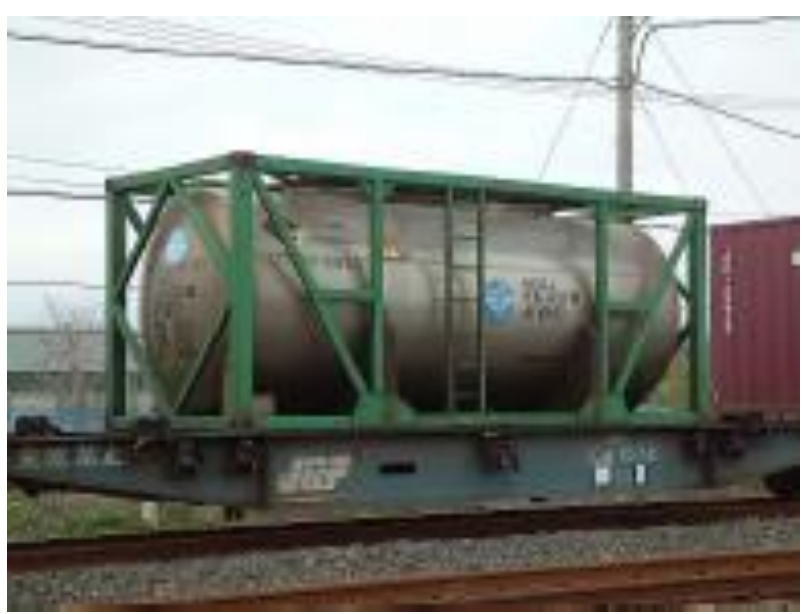

Fig. 2: A standard freight tank container,(Chatama [GFDL (URL 1) or CC BY-SA 3.0 (URL 2).

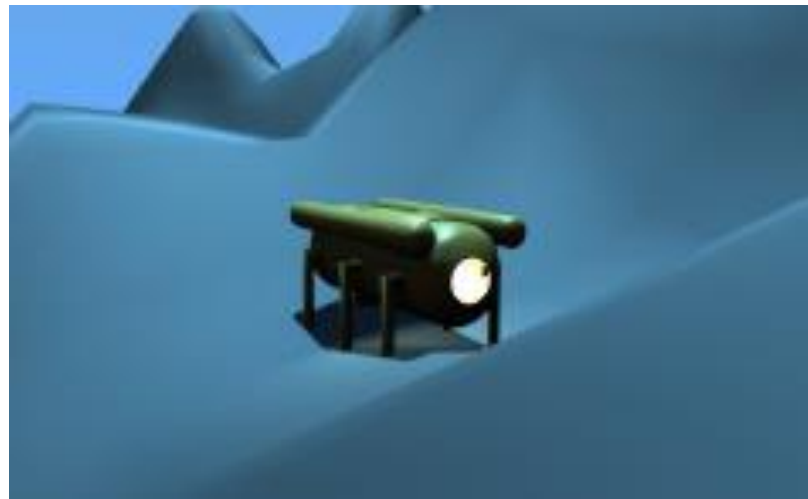

Fig. 3: Artistic rendering of the CalamarPark mobile habitat (courtesy CalamarPark.com)

- Mission in Tunisia for the PR campaign for a new aquarium

- Mission in Spain for a television program and live chats to nationwide schools

- Research on an antique shipwreck in Greece

- Commitment in Turkey for the PR of an environmental protection program

- Use of the outer shell for the placement of a sponsor logo

- Mission in Morocco for a study program of fish stocks 
- Mission in Italy as a temporary destination for recreational divers

It is intended that this mobile habitat will serve as a precursor and part of a larger, modular structure, permanently installed and providing large spaces for appropriate habitation. This habitat is to be extended with additional modules and can serve as the main base for other laboratories in the vicinity at various depths. It will be part of a seabed park that will be open to, assist and promote external ventures to develop new habitat concepts and their components in order to explore new living environments. As for stations in the arctic, space or on the moon there are unforeseeable benefits of a seabed habitation. One of the greatest accomplishments will be the direct and personal message, that the marine environment is not a distant and abstract term, but a vital part of our planets integrity. This proposal is therefore nothing less than a call for the construction of an international space station for the seabed.

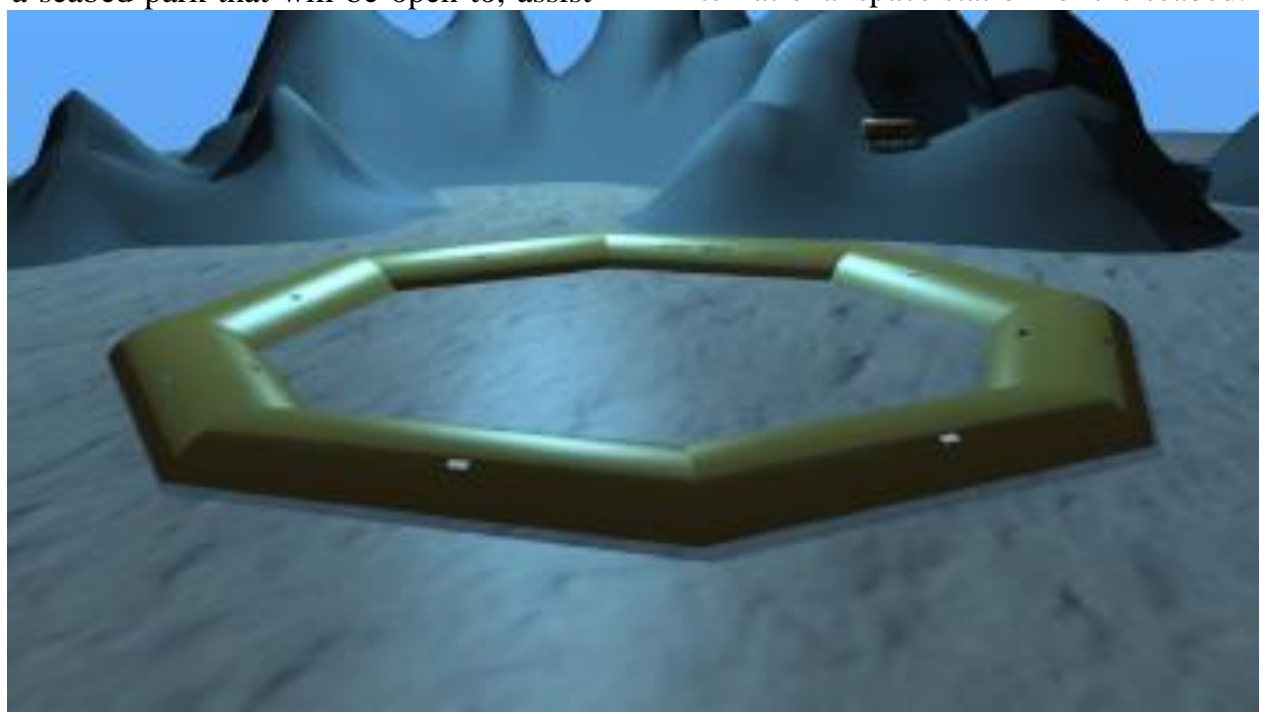

Fig. 4: A vision for an International Underwater Station (courtesy CalamarPark.com)

\section{References}

Burak, S., Doğan, E., Gazioğlu, C. (2004). Impact of urbanization and tourism on coastal environment, Ocean Coast Manag., 47 515-527, doi. 10.1016/j.ocecoaman.2004.07.007.

Hellwarth, B. (2012). Sealab, America's forgotten quest to live and work on the ocean floor, Simon \& Schuster.

Koblick, I., Miller, JW. (1984). Living and Working in the Sea, Van Nostrand Reinhold Company, New York $\mathrm{H}$.

Lettnin (1998). Diving with gas mixtures (orig.: Tauchen mit Mischgas), Springer, Berlin, Heidelberg.

URL 1. www.gnu.org/copyleft/fdl.html (23/09/2020)

URL 2. https://creativecommons.org (23/09/2020)

URL 3. www.mission-blue.org/2012/12/sylvia-earlereturns-to-historic-dive-site/ (23/09/2020)

Varinlioğlu, G., Pasin, B. (2018). Integrating Biomimicry and Geoinformatics: A Designerly Approach to Underwater Colonization, International Journal of Environment and Geoinformatics, 5(3), 260-272.doi.10.30897/ijegeo.414248

White, J. (2012). We Need to Maintain a Human Presence Under the Sea, New Scientist. 